\title{
Uterine Corpus Adenosarcoma pNO(i+) TNM Finding v8
}

National Cancer Institute

\section{Source}

National Cancer Institute. Uterine Corpus Adenosarcoma pNO(i+) TNM Finding v8. NCI

Thesaurus. Code C139867.

Uterine corpus adenosarcoma with isolated tumor cells in regional lymph node(s) no greater than $0.2 \mathrm{~mm}$. (from AJCC 8th Ed.) 